\title{
University Performance Satisfaction: A Student Experience in the Philippines
}

\author{
Kingie G. Micabalo ${ }^{1}$, Jesszon B. Cano ${ }^{2}$ and Ryan D. Montilla ${ }^{3}$ \\ ${ }^{183}$ University of Cebu , Cebu City, Philippines \\ ${ }^{2}$ Hospitality Management, Bohol Island State University - Candijay \\ University of Cebu, Cebu City, Philippines \\ E-mail:kmicabalo@uc.edu.ph, jesszon.cano@bisu.edu.ph,rmontilla@uc.edu.ph
}

\begin{abstract}
Student satisfaction is a factor to consider for a University in estimating its productivity and adequacy. It impacts not just how much an understudy appreciates time at college yet also estimates scholastic execution. This examination assesses the degree of understudy satisfaction in a College. The investigation respondents were the 183 understudies from the University of Cebu Lapu and Mandaue utilizing descriptive technique on simple random inspecting. The examination uncovered that most understudies were happy with the nature of schooling, current scholarly encounters, and understudy administrations. It was presumed that although general understandings were fulfilled, an area for development is still evident. Besides, to guarantee the greatest satisfaction, the division instructors must not lose sight of reasonable incentives for nonstop quality schooling improvement endeavors. The college must give an opportunity to emphatically vie for candidates and take care of inquiries quicker than any time in recent memory through an enlistment framework, installment framework, and the accessibility of web-based media augmentation for understudy concerns.

Keywords: Customer satisfaction, business and accountancy, descriptive study, Mandaue City, Philippines
\end{abstract}

\section{INTRODUCTION}

Consumer loyalty is the proportion of how the requirements and reactions are teamed up and conveyed to dominate client desire. It must be achieved if the client has a general decent connection with the provider. In the present rivalry, consumer loyalty is a significant presentation type and essential differentiator of business systems. Fulfillment is the most fitting name for the scope of mentalities and emotions that clients hold about their encounters with an association (Hill et al., 2007).

In the journey for scholastic greatness, Malaysia's public authority is worried about the climate in advanced education establishments. Advanced education is progressively perceived as the help industry. It put a more prominent accentuation on gathering the desires and needs of its taking interest clients who are the understudies. Because of exceptional rivalry, numerous colleges and universities face declining understudy enrolment, solve the issues of projects and administrations offered (Chuia et al., 2016). One route for colleges to achieve this goal is to put a recharged center around meeting or surpassing their understudies' desires and needs. In all colleges worldwide, understudy fulfillment has been viewed as a significant factor in estimating the institution's nature of administrations. Being the main recipient of the instructive educational administrations, understudies are in the correct situation to decide the nature of administrations offered by their college (Pamatmat, 2018). Further, understudies are confronting different life difficulties with unfriendly impacts on their scholarly presentation, universities failed to identify the understudies' needs, The issues mirror instructors' breaches in classroom management, instructional method, and absence of exercises that help understudies' comprehensive turn of events and compelling learning propensities (Dagdag et al., 2019).

In the Philippines, a gap exists where there is no examination on instructive organizations that tends to the proficiency and profitability execution of state colleges and schools, utilizing a more exact and solid methodology. The estimation of authoritative presentation and productivity is a change for all gatherings' overall government assistance, just as the nation. By estimating proficiency, it is conceivable to assess the exhibition of an association by contrasting it and the norm of global best practice (Castano\&Cabanda 2007). To pull in and hold understudies, colleges must distinguish and meet understudy desires that "understudy focused ness," "grounds atmosphere," and "instructional adequacy" strongly affect how fulfilled an understudy is with their general instructive experience.

Besides, the main viewpoints in estimating understudy fulfillment were those related to instructing and learning, while most un-significant were those related to the actual offices (Elliott and Healy, 2001).

The idea of the service product group is a substantial and solid instrument for the plan of a fulfillment study and fragments a University's administration offering so as to permit the board to target assets at those territories that are seen to be low fulfillment and high significance (Douglas et al., 2006). With the improvement of advanced education on the planet, the significance of understudies' fulfillment arose in advanced education writing. Toward the start, industrybased fulfillment models were applied to clarify understudy fulfillment and later created advanced education-based models to clarify it (Salinda et al., 2017). 
By the introduced circumstance, the researchers who are a college teacher instructing Business and Management decides the degree of understudy satisfaction in the College of Business and Accountancy. By the exploration directed, the analyst will have the option to suggest an action plan. Essentially, this examination anticipated the advantage of the University of Cebu Lapu-Lapu and Mandaue grounds.

\section{FRAMEWORK OF THE STUDY}

This investigation is anchored on the Theory of Customer Satisfaction by Philip Kotler, which expresses that satisfaction is an individual's sensations of weight or disappointment coming about because of an item's clear presentation (result) according to a person's desires. Purchaser steadfastness is the level of a person's felt state coming about due to taking a gander at a thing's reasonable introduction (result) comparing to the person's longings (Vanitha, 2012). As per Brown and Mazzarol (2008), understudy dependability is anticipated by understudy fulfillment, which is like this anticipated by the host college's clear picture.

While the apparent nature of "humanware" (e.g., individuals and cycle) and "equipment" (e.g., framework and specific help components) affects apparent worth, this was discovered to be powerless and vague. Of most significance was the effect of the foundation's institutional picture, which firmly anticipated apparent worth, and less significantly understudy fulfillment. Additionally upheld by Alves and Raposo (2007), who details a model that was tried through the usage of underlying conditions and demonstrated that the variable which has the most impact in understudy fulfillment in advanced education is the variable - picture followed by esteem and subsequently, quality perceived.

Program Theory further backs the investigation, which the hypothesis gives a lucid image of how change happens and how to improve execution. The Program Theory tells the best way to create, speak to, and use program hypothesis mindfully and deliberately to suit a specific circumstance. The requirements appraisal to intercession plan, from usage to results assessment, from strategy detailing to strategy execution and assessment, program hypothesis is fundamental (Funnell, \& Rogers, 2011). Program hypothesis as a bunch of unequivocal or understood suspicions by partners about what activity is needed to understand a social, instructive, or medical condition and why the difficult will react to this activity (Chen, 2012). The reason for Program Theory is not just to survey whether an intercession works or does not work, yet additionally how and why it does as such. The data is fundamental for partners to improve their current or future projects (Chen, 2012).

Program hypothesis is a methodical design of partners' prescriptive suppositions and certain presumptions entire projects, regardless of whether unequivocal or certain. Different suppositions, called the change model, manage what causal cycles are required to accomplish program objectives. Prescriptive suppositions, called the activity model, manage what moves must be made in a program to deliver alluring changes. Program theory uses the action model and change model to address contextual factors and planning and implementation issues that are greatly interested in stakeholders (Donaldson, 2012).

Further upheld by Action Model is a precise arrangement for orchestrating staff, assets, settings, and backing associations to arrive at an objective gathering and convey mediation administrations. The activity model comprises of the accompanying components: 1) executing association that surveys, improve, and guarantees its capacities: A program depends on an association to allot assets, to organize exercises, and to enroll, train, and direct implementers and other staff. How well a program is actualized might be identified with how well this association is organized. At first, guarantee that the executing association can actualize the program (Saunders, 2015).

The Investment Theory of understudies' fulfillment additionally bolsters the investigation where it delineated the conduct of understudies' fulfillment with scholarly execution from a speculation perspective. As per the hypothesis, the understudy sees time, energy, and exertion as speculation and looks to get back from it. As needs are, understudies will be fulfilled whenever remunerated, comparable to the speculation made (Barry and Okun, 2011).

As indicated by Elliott and Shin (2002), this expresses that an understudy's general fulfillment with his/her enlightening experience has customarily been estimated by a basic 'yes or no' question, or with one inquiry evaluating the large fulfillment. Even though this kind of inquiry is easy to reply and break down, understudies may not completely ponder their past reactions inside a poll regarding fulfillment with individual instructive properties when requested to survey their general fulfillment with a college based on a solitary inquiry.

Further upheld by the investigation of Paula et al. (2006), expressing that fulfillment overview is a screening instrument that distinguishes disappointed subjects. Minus any additional explanations, it is preposterous to expect to discover clients' particular issues and attempt to focus on stimulating activities. Client explicit remedies are infrequently observed as enhancements in generally speaking fulfillment rates.

As expressed by Razinkina et al. (2018), observing understudy fulfillment with training quality has become a necessary piece of the instructive cycle. Not just in various European colleges, which have utilized this checking for quite a long time, but also in Russian colleges, which are keen on quality improvement. Driving colleges in Russia, including Peter the Great St. Petersburg Polytechnic 
University, are executing arrangements focused on expanding understudy fulfillment with advanced education quality. Instruction quality checking as a critical component in giving input to understudies contributes enormously to this cycle.

\section{OBJECTIVES OF THE STUDY}

The examination expects to conclude the degree of understudy satisfaction at the College of Business and Accountancy. The consequence of this investigation filled the output of program activity plan to ensure its significance to students' current and future needs. It also recognizes the respondents' profile regarding age, sexual orientation, common status, and year level. It distinguishes the degree of satisfaction seen by the understudies in the aspects of training, scholastic encounters, and the fulfillment of understudy administrations.

\section{METHODOLOGY}

\section{A. Research Design}

This study utilized a descriptive method to conclude the degree of student fulfillment at the College of Business and Accountancy.

\section{B. Research Site}

The research was conducted at the University of Cebu Lapu-Lapu and Mandaue campus located at A.C. Cortes Ave., Mandaue City. It offers Accountancy,Business Administration, having four majors, namely; Management Accounting, Marketing Management, Financial Management, and Human Resource Development Management.

\section{Respondents}

The 183 respondents of the exploration study were the College of Business and Accountancy department students determined through Slovin's formula on a simple random sampling.

\section{Instrumentation}

The researchers adapted the University Research and Statistics Office student satisfaction survey in the questionnaire profiling. The preliminary section is the respondent's profile. The second part pertains to determining satisfaction in quality of education, academic experiences, and student service satisfaction.

\section{E. Treatment of Data}

Frequency and simple percentage, and Mode were used to treat the accumulated information.

\section{F. Research Procedure}

\section{Data Gathering}

To accomplish the exploration study, these means were followed. Letter of aim routed to the Dean for information gathering, asking license to cost the study and to acquire the absolute number of understudies enlisted. The surveys were managed through the employees taking care of subjects in the office. The information was being classified and broke down at the University Research and Statistics Office.

\section{RESULTS AND DISCUSSION}

This area outlays the information assembled. The first section details the respondent's demographic profile. For the subsequent part, it presents the information fair and square of fulfillment saw by the understudies regarding nature of training, scholarly encounters, and the fulfillment of understudy administrations

TABLE 1 PROFILE OF THE RESPONDENTS (N=183)

\begin{tabular}{|c|c|c|}
\hline & Frequency & Percentage \\
\hline Age & & \\
\hline 18 & 32 & 17.00 \\
\hline 19 & 111 & 61.00 \\
\hline 20 & 30 & 16.00 \\
\hline 21 & 10 & 5.00 \\
\hline Gender & & \\
\hline Male & 38 & 21.00 \\
\hline Female & 145 & 79.00 \\
\hline Civil Status & & \\
\hline Single & 181 & 99.00 \\
\hline Married & 2 & 1.00 \\
\hline
\end{tabular}

Table I presents the demographic profile of the understudies dependent on age, sexual orientation, and common status. It shows that by far most of the respondents developed 19 and is equivalent to $61 \%$. This data construes that most of the understudies were in the first year level. Concurring Robinson (2017), the main motivation to bounce directly from secondary school to school at age 18-19 is energy. School is hard, and remaining zeroed in on intense, exhausting classes can be particularly hard for understudies who have a touch of involvement in the rest of the world. Numerous youngsters go through a year acquiring full-time pay and conclude they need not bother with school. That move may look good for a very long time, yet the National Center for Education Statistics insists that school graduates have much better business openings as time goes on.

Bouncing directly into school dodges the allurement of a solid beginning in the labor force. Concerning sexual orientation, the majority of $79 \%$ of the understudies were female. It shows that the female has more tendencies to take 
the course. Concerning the common status, a large portion of the respondents was single or equal to $99 \%$.t This is additionally upheld as per Kadel J. (2017), which expresses that the clearest bit of leeway of being single at college is that you possess more energy for yourself, regardless of whether that implies going out with your companions or organizing your investigations.

\section{TABLE II LEVEL OF SATISFACTION AS REVEALED BY THE} RESPONDENTS

\begin{tabular}{|l|c|c|c|}
\hline $\begin{array}{l}\text { A. Generally fulfillment } \\
\text { with the nature of } \\
\text { UCLM training. }\end{array}$ & Mean & Interpretation & Rank \\
\hline $\begin{array}{l}\text { Safety and security of } \\
\text { UCLM campus }\end{array}$ & 2.43 & Very Satisfied & 1 \\
\hline $\begin{array}{l}\text { Academic integrity of the } \\
\text { campus }\end{array}$ & 2.25 & Satisfied & 2 \\
\hline Orientation program & 2.17 & Satisfied & 3 \\
\hline $\begin{array}{l}\text { Formal academic } \\
\text { experience }\end{array}$ & 2.14 & Satisfied & 4 \\
\hline $\begin{array}{l}\text { Organized out-of-class } \\
\text { experiences such as } \\
\text { intramurals }\end{array}$ & 2.11 & Satisfied & 5 \\
\hline $\begin{array}{l}\text { Informal out-of-class } \\
\text { experiences such as } \\
\text { hearing speakers, student } \\
\text { discussions }\end{array}$ & 2.10 & Satisfied & 6 \\
\hline Overall Mean & 2.20 & Satisfied & \\
\hline
\end{tabular}

Table II shows the after effects of the evaluation of the Accountancy understudies fair and square of fulfillment. There were three criteria for customer satisfaction in the College of Business and Accountancy. The principal measure, which is the fulfillment with the nature of UCLM instruction, has six pointers. Concerning the wellbeing and security of the UCLM grounds showed on the first criterion recorded the highest mean at 2.43 and interpreted as Very Satisfied. As per First Security (2016), presently, like never before previously, the two guardians and potential school candidates are calculating in the wellbeing record of grounds in their choice of which schools to apply to and additionally join in. Ground security is a significant issue today.

It is significant for grounds to have the vital security set up to proactively keep any violations from happening, just as to give everybody a suspicion that all is well and good. What is more, schools are taking more notification of their wellbeing records, particularly for public picture purposes.

As for Informal out-of-class experiences such as hearing speakers and student discussions recorded the lowest mean at 2.10 and interpreted as Satisfied. The table shows a general interpretation of satisfaction by the students having an overall mean of 2.20. In spite of the way that the overall comprehension of the table was satisfied, there is so far a need to improve the idea of guidance being constrained by the University, particularly in the Informal out-of-class experiences, for instance, hearing speakers and understudy discussions. It was additionally upheld by O'Neill and Palmer (2004), which underpins the need to create legitimate, substantial, and replicable proportions of administration quality. It proposed that instructors must not dismiss the first reason these measures were planned,such as their handy incentive to educate consistent quality improvement endeavors.

\section{TABLE III LEVEL OF SATISFACTION AS REVEALED BY THE} RESPONDENTS

\begin{tabular}{|l|c|c|c|}
\hline $\begin{array}{l}\text { B. Fulfillment with the } \\
\text { current scholastic } \\
\text { encounters with UCLM. }\end{array}$ & Mean & Interpretation & Rank \\
\hline $\begin{array}{l}\text { Extent through which the } \\
\text { faculty included } \\
\text { multicultural perspective in } \\
\text { the classroom presentation, } \\
\text { assignments, or } \\
\text { discussions. }\end{array}$ & 2.10 & Satisfied & 1 \\
\hline $\begin{array}{l}\text { Quality of Laboratory } \\
\text { facilities }\end{array}$ & 2.03 & Satisfied & 2 \\
\hline Nature of instructing & 2.02 & Satisfied & 3 \\
\hline $\begin{array}{l}\text { Use of technology in } \\
\text { classes }\end{array}$ & 1.98 & Satisfied & 4 \\
\hline $\begin{array}{l}\text { Occasionto take an interest } \\
\text { in anexamination venture } \\
\text { with an employee. }\end{array}$ & 1.90 & Satisfied & 5 \\
\hline Quality of classroom & 1.87 & Satisfied & 6 \\
\hline Enrollment process & 1.72 & Satisfied & 7 \\
\hline Overall Mean & 1.95 & Satisfied & \\
\hline
\end{tabular}

Table III shows the evaluation aftereffects of the Accountancy understudies fair and square of fulfillment on the subsequent model, which is fulfillment on the current scholastic encounters with UCLM, which has seven pointers. The Extent through which the faculty included a multicultural perspective in the classroom presentation, assignments, or discussions recorded the highest mean at 2.10 and interpreted as Satisfied.

Upheld by Stanley and Quellett (2019), it brings an abundance of foundation and encounters, including a large group of numerous social and social characters that shape how an individual considers and views the world around. Assisting a person with figuring out how to sort out self, what is going on in the general public and world, and acceptable behavior despite complex cultural and worldwide difficulties? The resources prepared in a specific specialized topic frequently show the best approach to learning.

It is not outfitted with the ability to draw in instructing techniques that are basic for improving basic speculation aptitudes around various related qualities and learning results. These instructing strategies set aside some effort to create and requires a commonly gainful learning cycle of preliminary, reflection, and appraisal with understudies to advance comprehension of various perspectives and social skill. 
As for the Enrollment process, which recorded the lowest mean at 1.72 interpreted as Satisfied, the table shows a general interpretation of satisfied as perceived by the students having an overall mean of 1.95. Although the overall interpretation of the table wassatisfied, improvement is evident in the current academic experiences with the UCLM, particularly with the enrollment process.
As indicated by Jenny (2018), the understudies were not just searching for customized consideration at each progression, yet also hoping to get it fast. Enlistment frameworks, when executed effectively, give confirmation groups a superior influence over understudy needs and inspirations. The whole cycle, from contact to change, gets consistent with a unified framework set up.

TABLE IV LEVEL OF SATISFACTION AS REVEALED BY THE RESPONDENTS

\begin{tabular}{|l|c|c|c|}
\hline \multicolumn{1}{|c|}{ C. Satisfaction with student services } & Mean & Interpretation & Rank \\
\hline Campus Chapel & 2.30 & Satisfied & 1 \\
\hline DEAN's office & 2.21 & Satisfied & 2 \\
\hline CAD's office & 2.21 & Satisfied & 2 \\
\hline SAO & 2.14 & Satisfied & 3 \\
\hline The Accounting section & 2.14 & Satisfied & 3 \\
\hline Service of the advising office/ guidance office & 2.11 & Satisfied & 4 \\
\hline Registrar's office & 2.08 & Satisfied & 5 \\
\hline Canteen & 2.05 & Satisfied & 6 \\
\hline EDP & 2.02 & Satisfied & 7 \\
\hline The Cashiers office & 2.01 & Satisfied & 8 \\
\hline Service of the University Clinic & 1.96 & Satisfied & 9 \\
\hline Comfort Rooms & 1.89 & Satisfied & 10 \\
\hline Computer support facilities in the library & 1.89 & Satisfied & 10 \\
\hline Campus free Internet connection & 1.86 & Satisfied & 11 \\
\hline Study Hall & 1.86 & Satisfied & 11 \\
\hline Overall Mean & 2.05 & Satisfied & \\
\hline
\end{tabular}

Table IV shows the evaluation consequences of the Accountancy understudies fair and square of fulfillment on the third basis, which is fulfillment on understudy administrations, which has fifteen indicators.

As for the Campus Chapel, it recorded the highest mean at 2.30 and was interpreted as Satisfied. As per Peck (2016), the house of prayer empowers understudies to take an interest in corporate love drove and encompassed by their companions. Understudy authority groups help organize the house of prayer, guaranteeing dynamic and significant programming.

Sanctuary gives unmistakable love encounters that urge people to praise their extraordinary confidence conventions. Furthermore, church administrations exhibit the college's obligation to developing followers and researchers.

Church gives an inherent break considering profound rest amid the thoroughness and requests of school life and the fuse of confidence into an understudy's everyday schedule. As for Study Hall, the lowest mean at 1.86 was interpreted as Satisfied. The table shows a general interpretation of satisfaction as perceived by the students having an overall mean of 2.05. Despite the fact that the general translation of the table was fulfilled, there is as yet a need to improved understudy administrations' fulfillment, especially with the Study corridor. It was additionally upheld by Partnership

(2013), expressing that as of late, numerous teachers have scrutinized the utility and estimation of the conventional

investigation corridor and unstructured timeframe spent in a daintily regulated homeroom. Given that there are only a set number of hours in the school day and that various understudies may be neglecting to meet desires or not getting the help they need to succeed academically.

Numerous schools are supplanting customary examination corridors with more organized scholarly help periods, warnings, learning labs, and different methodologies, or they are relinquishing them by and large.

The essential reasoning is that unstructured examination lobbies waste valuable time that could be utilized all the more deliberately to help understudies who are battling scholastically or give more valuable, significant, and advancing learning encounters. 
TABLE V SUMMARIZED DATA ON THE LEVEL OF CUSTOMER SATISFACTION AS PERCEIVED BY THE RESPONDENTS

\begin{tabular}{|l|c|c|}
\hline & Mean & Interpretation \\
\hline A. In general fulfillment with the nature of UCLM schooling. & 2.20 & Satisfied \\
\hline B. Fulfillment with the current scholastic encounters with UCLM. & 1.95 & Satisfied \\
\hline C. Satisfaction with student services & 2.05 & Satisfied \\
\hline Grand Mean & 2.06 & Satisfied \\
\hline
\end{tabular}

Table $\mathrm{V}$ shows the summarized data on the level of Customer Satisfaction. It shows that the first criterion, which is the overall satisfaction of UCLM education quality, got the highest mean at 2.20 and was interpreted as Satisfied. Despite the fact that the general translation was fulfilled, there is as yet a need to improve UCLM training quality's general fulfillment.

It is upheld as indicated by Butt and Rehman's (2010) investigation, which centers around the components like educators' ability, courses offered, learning climate, and study hall offices. As indicated by the investigation, the consequences of relapse examination uncover that all credits have a huge and positive effect on understudies' fulfillment in advanced education, however, with changing the level of solidarity. Instructors' mastery is the most persuasive factor among all the factors; consequently, it requires the policymakers and organizations' uncommon consideration.

The fulfillment on understudy administrations got the most minimal mean at 2.05 and deciphered as Satisfied. It means that there was evidence that customer satisfaction indicators were achieved in many cases. Although the overall interpretation was satisfied, there is still a need to improve satisfaction on student services. As per Gruber et al. (2010), understudies' fulfillment with the college depends on a moderately steady person

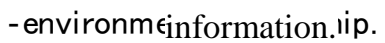

Along these lines, understudies' fulfillment appears to reflect very much apparent quality contrasts of offered administrations and the more extensive climate. Understudies were especially happy with the school positions and the environment among understudies. Understudies were generally disappointed with the college structures and the nature of the talk theaters.

\section{CONCLUSION}

Understudy fulfilment is a factor to consider for a University in estimating its productivity and adequacy. It impacts not just how much an understudy appreciates time at college yet additionally gauges scholastic execution. The evaluations, course support, associations with speakers, participation, and employability once they leave are all somewhat dependent on how much an understudy appreciated college time. Not just understudy fulfillment, which is essential for advancing life at the foundation. However, it can likewise
Yield a significant effect on a college's remaining in worldwide rankings. To guarantee the greatest fulfillment as far as the nature of schooling in the College of Business and

Accountancy, the division instructors must not dismiss the first reason these measures were planned, such as the handy incentive in educating persistent quality improvement endeavors.Moreover, to guarantee the greatest fulfillment regarding the current scholarly encounters, the college must think of an enlistment framework. With all tech stages, enlistment frameworks offer certain highlights that join to take care of business, expanding enlistment proficiency for this situation.

These highlights settle on the choice to receive a viable answer for affirmations, a truly shrewd one for it gives an opportunity to firmly go after candidates and take care of inquiries quicker than at any other time. Concerning the greatest fulfillment of consumer loyalty as far as understudy benefits, specifically with the Study lobby, the college ought to give a more extensive climate to understudies. Understudies were especially happy with the school situations and the climate that hushes up, helpful for learning, and a decent region for considering. The college must give essential assets, for example, longer Wi-Fiassociations for the understudy to surf and research for

\section{REFERENCES}

[1] H. Alves and M. Raposo, "Conceptual Model of Student Satisfaction in Higher Education,” Total Quality Management \& Business Excellence, Vol.18, No.5, pp.571-588. Retrieved from https://bit.ly/3n0Uuwo, 2007.

[2] C.Y. Barry and M.A. Okun, Application of Investment Theory to Predicting Maintenance of the Intent to Stay among Fresh men. Journal of College Student Retention: Research, Theory \& Practice, Vol. 13, No.1, pp.87-107. Retrieved from https://bit.ly/3n23pOk, 2011.

[3] R. M. Brown, Mazzarol, T. W. "The importance of institutional image to student satisfaction and loyalty within higher education, "Higher Education, Vol.58, No.1, pp. 81-95. Retrieved from https://bit.ly/3lPNCR6.

[4] B.Z.Butt and K. Rehman, "A study examining students' satisfaction in higher education.” Procedia - Social and Behavioral Sciences,Vol.2, No.2, pp.5446-5450. Retrieved from https://bit.ly/33TbrS6, 2010.

[5] M.C.N. Castano and E. Cabanda, "Sources of Efficiency And Productivity Growth In The Philippine State Universities And Colleges: A Non-Parametric Approach," International Business \& Economics Research Journal (IBER), Vol.6, No.6. Retrieved from https://bit.ly/3gmVmsR, 2007.

[6] H. T. Chen, "Theory-driven evaluation: Conceptual framework, application, and advancement. Retrieved from https://bit.ly/2JB8hvj

[7] T.B. Chuia, M.S. Ahmadb, F.A. Bassimc and N.A. Zaimid, "Evaluation of Service Quality of Private Higher Education using 
Service Improvement Matrix," Procedia - Social and Behavioral Sciences. pp. 132-140. Retrieved from https://bit.ly/39Z4aUi, 2016.

[8] J.D. Dagdag, H.G. Cuizon, A.O. Bete, “College students' problems and their link to academic performance: Basis for needs-driven student programs," Journal of Research, Policy \& Practice of Teachers and Teacher Education, Vol.9, No. 2, pp.54-65. Retrieved from https://bit.ly/33QXC6q, 2019.

[9] J. Douglas, A. Douglas, B. Barnes, "Measuring student satisfaction at a UK university," Quality Assurance in Education, Vol.14, No.3, pp. 251-267. Retrieved from https://bit.ly/3lVnnZB, 2006.

[10] S. Donaldson, "Strategies and Applications: Program Theory-Driven Evaluation Science," Hove, East Sussex BN3 2FA, New York: Routledge. Retrieved from https://bit.ly/3mVZthH, 2012.

[11] K.M. Elliott and M.A. Healy, "Key Factors Influencing Student Satisfaction Related to Recruitment and Retention," Journal of Marketing for Higher Education, Vol.10, No.4, pp. 1-11. Retrieved from https://bit.ly/2VQSACB, 2001.

[12] K.M. Elliott, D. Shin, "Student Satisfaction: An alternative approach to assessing this important concept," Journal of Higher Education Policy and Management, Vol. 24, No.2, pp.197-209. Retrieved from https://bit.ly/2IqXmnb, 2002.

[13] First Security, "Why Campus Security Is More Important than Ever," Retrieved from https://bit.ly/36SRjRF

[14] C. Funnell and P.J. Rogers, "Purposeful Program Theory: Effective Use of Theories of Change and Logic Models," Retrieved from https://bit.ly/3gskjmK, 2011.

[15] T. Gruber, S. Fuß, R. Voss and M. Gläser-Zikuda, "Examining student satisfaction with higher education services. International Journal of Public Sector Management, Vol.23, No.2, pp. 105-123. Retrieved from https://bit.ly/3ownNav, 2010.

[16] N. Hill, G. Roche and R. Allen, "The Customer Experience Through the Customer's Eyes,” The Leadership Factor, 2007: 0955416116, 9780955416118. Retrieved from https://bit.ly/36UOekn, 2007.

[17] J. Jenny, "What is an enrollment system, and why does it matter," Retrieved from https://bit.ly/3qCrTQi, 2018.

[18] J. Kadel, "Being Single at University Vs. Being in A Relationship," Retrieved from https://bit.ly/2VPDahM, 2017.

[19] M.A. O'Neill and A. Palmer, "Importance-performance analysis: A useful tool for directing continuous quality improvement in higher education,” Quality Assurance in Education, Vol.12, No.1, pp.39-52. Retrieved from https://bit.ly/3lUGhjj, 2004.

[20] F. Pamatmat, "Service Quality Dimensions Of A Philippine StateUniversity And Students' Satisfaction: Bridging Gaps To Excellence," International Journal of Advanced Research, Vol. 6, No.7, pp.673-681. Retrieved from https://bit.ly/39QNezq, 2018.

[21] I. Paula, Oja., Timo T. Kouri., and J. Arto Pakarinen. "From customer satisfaction survey to corrective actions in laboratory services in a university hospital," International Journal for Quality in Health Care, Vol. 18, No. 6 Retrieved from https://bit.ly/39Mkfge,2006.

[22] G.S. Partnership, Study Hall Definition. Retrieved from https://bit.ly/36V0P6X, 2013.

[23] A. E. Peck, Why Chapel? Retrieved from https://bit.ly/3mZHGGz, 2016.

[24] E. Razinkina, L. Pankova, L.Trostinskaya, I. Pozdeeva, L. Evseeva and A. Tanova, "Student satisfaction as an element of education quality monitoring in an innovative higher education institution,". EDP Sciences, Retrieved from https://bit.ly/2JZolkM, 2018.

[25] Robinson, "Good Reasons to Go to College at 18 Years of Age," Retrieved from https://bit.ly/39QWdRa, 2017.

[26] W.R. Salinda and S. Lalitha Fernando, "Students' Satisfaction in Higher Education in Literature Review," American Journal of Educational Research.2017, Vol. 5, No.5,pp.533-539.Retrievedfrom ttps://bit.ly/2VTWyKC, 2017.

[27] R. Saunders, "Implementation of Monitoring and Process Evaluation," The United States of America: SAGE Publications, Inc. Retrieved from https://bit.ly/3qCqUPT, 2015.

[28] C.A. Stanley and M.L. Quellett, "Helped students to interpret subject matter from diverse perspectives,” Retrieved from https://bit.ly/2Le1GHr, 2019.

[29] D. Vanitha, "Customer Relationship Management on Customer Satisfaction," International Journal of Scientific Research, Vol.3, No.4, pp.1-3. Retrieved from https://bit.ly/39Q5lFA, 2012. 